\title{
MANAJEMEN PENGEMBANGAN SDM DI PONDOK PESANTREN AS-SYAFAAH KEBONSARI JEMBER
}

\author{
Abdul Mu'is \\ Institut Agama Islam Negeri (IAIN) Jember \\ abdulmuisjbr@gmail.com
}

\begin{abstract}
Abstrak:
Tujuan dari penelitian ini adalah untuk mendeskripsikan perencanaan, pelaksanaan dan evaluasi pengembangan sumber daya manusia di Pondok Pesantren As-Syafaah. Penelitian ini menggunakan pendekatan kualitatif dengan desain studi kasus. Bentuk data dalam penelitian ini adalah data primer dan data sekunder yang diperoleh dari informan dan dokumen pendukung. Analisis data dilakukan dalam beberapa tahap menurut teori Miles, Huberman dan Saldana, yaitu kondensasi data, penyajian data, dan penarikan kesimpulan atau verifikasi. Hasil penelitian menunjukkan bahwa (1) analisis kebutuhan pengembangan sumber daya manusia analisis kualitas dan kuantitas, (2) pelaksanaan pengembangan sumber daya manusia dilakukan melalui rekrutmen, program pendidikan dan pelatihan, dan pembentukan budaya pesantren; (3) evaluasi pengembangan sumber daya manusia dititikberatkan pada perubahan sikap dan perilaku dalam menjala nkan peran dan tanggung jawab.
\end{abstract}

Kata kunci: manajemen, SDM, pesantren

\begin{abstract}
:
The aim of this is to describe the planning, implementation and evaluation of human resource development at Assyafaah Islamic boarding school. This study used a qualitative approach with case study design. The form of data in this study is primary data and secondary data obtained from informants and supporting documents. Data analysis is carried out in several steps according to Miles, Huberman and Saldana theory, which are data condensation, data display, and drawing conclusions or verification (conclusion drawing and verification). The results shown that (1) analysis of buman resource development needs quality and quantity analysis, (2) implementation of human resource development is carried out through recruitment, education and training programs, and the formation of Islamic boarding school culture; (3) evaluation of human resource development is emphasized on changing attitudes and behaviors in carrying out roles and responsibilities.
\end{abstract}

Keywords: management, SDM, pesantren

\section{PENDAHULUAN}

Pondok pesantren memiliki fungsi yang meliputi pendidikan, dakwah dan pemberdayaan masyarakat (Presiden Republik Indonesia, 2019) karena itu pesantren memiliki kontribusi nyata dalam pembangunan di Indonesia. Apalagi dilihat secara historis, pesantren memiliki pengalaman yang luar biasa dalam membina dan mengembangkan masyarakat. Bahkan, pesantren mampu meningkatkan perannya secara mandiri dengan menggali potensi yang dimiliki masyarakat di sek elilingnya. Fungsi pesantren sebagai lembaga pendidikan merupakan bentuk partisipasi masyarakat 


\section{Manajemen Pengembangan SDM Di Pondok Pesantren As-Syafaah}

dalam bidang pendidikan karena pada dasarnya pendidikan merupakan tanggung jawab pemerintah dan masyarakat (Indonesia, 2003). Dalam praktiknya, banyak lembaga kemasyarakatan yang terlibat dan mengambil peran dalam penyelenggaraan pendidikan di Indonesia. Berbagai yayasan sebagai badan penyelenggara pendidikan mendirikan satuan-satuan pendidikan dalam berbagai jenjang, mulai dari jenjang pendidikan dasar hingga pendidikan tinggi. Satu hal yang menarik adalah adanya satuan pendidikan yang diselenggarakan oleh masyarakat dengan segala latar belakang budaya dan agama yang memberi ciri khas satuan pendidikan tersebut yang oleh undang-undang dilindungi oleh pemerintah. Perlindungan dan pengakuan adanya ciri khas tersebut merupakan konsekuensi logis dari sistem pendidikan nasional dalam realita kebhinekaan bangsa Indonesia.

Pesantren adalah salah satu lembaga pendidikan yang lahir dan berkembanga di tengahtengah masyarakat yang sifatnya mandiri dan mengakar dimasyarakat, karena itu pendidikan pesantren memiliki ciri khas tersendiri sehingga membedakan dengan lembaga pendidikan lainnya. Pendidikan Pesantren adalah pendidikan yang diselenggarakan oleh Pesantren dan berada di lingkungan Pesantren dengan mengembangkan kurikulum sesuai dengan kekhasan Pesantren dengan berbasis kitab kuning atau dirasah Islamiah dengan pola pendidikan muallimin (Presiden Republik Indonesia, 2019). Pesantren merupakan lembaga pendidikan Islam pertama dan khas pribumi yang ada di Indonesia pada saat itu. Tapi, sejak kapan mulai munculnya pesantren, belum ada pendapat yang pasti dan kesepakatan tentang hal tersebut. Belum diketahui secara pasti tahun berapa pesantren pertama kali muncul sebagai pusat pendidikan agama di Indonesia, Ronald menyatakan bahwa pesantren pertama kali dirintis oleh Syeikh Maulana Malik Ibrahin pada tahun 1399 M (Bull, 1977). Sementara Steenbrink menyebutkan bahwa Pesantren yang paling lama di Indonesia namanya Tegalsari di Ponorogo Jawa Timur (Steenbrink, 1994)· Pondok Pesantren Tegalsari didirikan pada akhir abad ke-18. Pesantren memiliki sejarahnya yang panjang. Karena itu wajar kiranya ia disebut sebagai lembaga pendidikan tradisional Islam (Fatoni, 2006). Beberapa definisi mencoba mengurai tentang pesantren atau pondok pesantren diantaranya, Pondok Pesantren (Ziemek, n.d.) merupakan lembaga pendidikan Islam yang menempatkan sosok kiai sebagai tokoh sentral dan masjid sebagai pusat lembaganya (Raharjo, 1995). Lembaga ini merupakan institusi pendidikan Islam tertua di Indonesia dan sekaligus bagian dari warisan budaya bangsa (indigenous culture) (Zarkasyi, 1998). Ia adalah lembaga keagamaan yang mendidik manusia agar mampu berpegang teguh pada al-Qur'an dan mengikuti sunnah Rasulullah saw sehingga menjadi pribadi yang mempunyai komitmen dan konsistensi dalam setiap waktu dan kondisi (Fatoni, 2006). Dalam konteks pendidikan nasional, pesantren merupakan bagian dari pendidikan 
keagamaan (Presiden Republik Indonesia, 2007) sebagaimana diantur dalam PP 55/2007 yang menyatakan bahwa Pendidikan keagamaan Islam berbentuk pendidikan diniyah dan pesantren.

Pondok pesantren sebagai lembaga pendidikan keagamaan setidaknya memiliki lima unsur yang harus terpenuhi secara integral (Dhofier, 1982) yaitu Kyai, Santri yang mukim,Asrama atau pondok, Musollah, dan kajian kitab kuning. Dalam pembelajarannya pesantren menggunakan metode weton, sorogan, dan bandongan, yang sekarang telah berkembang dengan sistem klasikal atau madrasah. Keberadaan pondok pesantren sebagai lembaga pendidikan Islam sangat bergantung pada komitmen masyarakat sebagai pengelolanya, maka wajar jika sejak awal pertumbuhannya pondok pesantren memiliki bentuk beragam dan tidak ada suatu standarisasi yang berlaku bagi semua pesantren. Meskipun bentuk pondok pesantren beragam, namun secara umum keberadaan pondok pesantren yang asli selalu dicirikan oleh standarisasi kitab-kitab klasik yang menjadi buku teks pelajaran wajib (kutubul muqarrarah) yang dimasyarakat dikenal dengan sebutan kitab kuning beserta metode pengajarannya. Pondok pesantren sebagai salah satu lembaga pendidikan masyarakat yang keberadaannya dikelola langsung oleh masyarakat, dalam praktiknya harus mampu mempertahankan eksistensinya sehingga keberadaannya tetap diakui dan dibutuhkan oleh masyarakat, Namun demikian banyak ditemukan adanya pondok pesantren yang justru tidak mampu mengikuti perkembangan. Faktor regenerasi sumber daya manusia yang gagal memperlihatkan kondisi pesantren yang boleh dikata "hidup segan mati tak mau". Keberadaan pondok pesantren dengan kondisi seperti ini hanya tinggal menunggu waktu untuk lenyap hingga terlupakan oleh masyarakat. Maka penting dalam hal ini pesantren menyiapkan generasi penerus yang tentunya mampu untuk mempertahankan eksistensinya ditengah masyarakat. Salah satu strategi yang perlu dilakukan untuk tetap menjaga eksistensi pondok pesantren adalah melalui pengembangkan Sumber Daya Manusianya. Pengembangan SDM ini penting dilakukan dipondok pesantren untuk dapat memberikan jaminan kualitas lulusan yang dihasilkan oleh pondok pesantren, karena bagaimanapun juga lulusan pondok pesantren yang telah menyelesaikan pendidikannya akan berhadapan langsung dengan masyarakan sebagai pengguna lulusan tersebut. Oleh sebab itu, pengembangan SDM harus mendapat perhatian sungguh-sungguh berdasarkan perencanaan sistematik dan rinci yang mengacu kemasa depan.

\section{METODE}

Berdasarkan konteks penelitian ini, fokus penelitian ini di tetapkan pada aspek: (1) perencanaan pengembangan SDM pada pondok pesantren, (2) implementasi pengembangan SDM pada pondok pesantren dan (3) evaluasi pengembangan SDM. Penelitian ini penting terutama bagi pengelola pondok pesantren untuk dapat menjadi bahan kajian yang akan membantu 


\section{Manajemen Pengembangan SDM Di Pondok Pesantren As-Syafaah}

dalam proses berfikir inovatif dalam menumbuhkembangkan institusi pondok pesantren. Dalam penelitian ini, data yang akan dikumpulkan dikelompokkan menjadi dua jenis yaitu data primer dan data sekunder. Data primer diperoleh dalam bentuk verbal berupa kata-kata, ucapan lisan dan perilaku dari subjek (informan) berkaitan dengan perencanaan, implementasi dan evaluasi pengembangan SDM pada pesantren As-syafaah. Sedangkan data sekunder bersumber dari dokumen-dokumen, foto-foto, benda-benda yang dapat digunakan sebagai informasi pelengkap data primer. Karakteristik data sekunder ini dapat berupa tulisan-tulisan, rekaman-rekaman, gambar gambar atau foto-foto yang berhubungan dengan pengembangan SDM pada pesantren tersebut. Sumber data dalam penelitian ini adalah manusia yang berkedudukan sebagai informan. Informan yang dipilih dalam penelitian ini memiliki empat karakteristik sebagai berikut: (1) informan memahami kultur dan terlibat dengan kegiatan rutin dipesantren te rsebut, (2) informan terlibat dilapangan pada saat penelitiaan. Data yang diperoleh haruslah holistik dan integratif serta relevan dengan fokus dan tujuan penelitian. Maka untuk dapat mencapai semua itu, peneliti menggunakan tiga teknik dalam mengumpulkan data, yaitu : (1) wawancara mendalam (2) bservasi partisipan dan (3) studi dokumentasi. Penelitian ini dianalisa melalui teori Miles, Huberman dan Saldana.

\section{HASIL DAN PEMBAHASAN}

Manajeman adalah "The art of getting things done through otherpeople" (seni menyelesaikan segala sesuatu melalui orang lain) (Tunggal, 2002). Sementara Terry menyatakan Manajemen merupakan sebuah proses yang khas, yang terdiri dari tindakan-tindakan: perencanaan, pengorganisasian, menggerakkan dan pengawasan, yang dilakukan untuk menentukan serta mencapai sasaransasaran yang telah ditetapkan melalui pemanfaatan sumber daya manusia serta sumber-sumber lain. Manajemen adalah ilmu pengetahuan ataupun seni (Terry, 1992). Pada dasarnya merupakan tiga fungsi manajemen yaitu : perencanaan ( Planning), Pelaksanaan (Execution) dan evaluasi (evalution) (Nurdin, 2007) Karena itu dalam penelitian ini di fokuskan pada :

a. Perencanaan Pengembangan SDM pada Pondok Pesantren, Perencanaan pengembangan SDM pada pondok pesantren merupakan upaya yang dilakukan oleh pondok pesantren dalam rangka menyiapkan keputusan keputusan yang berkaitan dengan program pengembangan SDM pada pondok pesantren. Perencanaan SDM adalah sebuah proses yang melibatkan serangkaian kegiatan seperti peramalan atau estimasi, usaha pemenuhan kebutuhan tenaga kerja organisasi dalam jangka waktu tertentu di masa mendatang didalamnya meliputi upaya pencocokkan SDM internal dan eksternal dengan lowongan lowongan pekerjaan yang diperkirakan akan dibutuhkan (Mondy, 2008), pengaturan flow SDM serta pendayagunaan 
sumber daya yang tersedia secara efektif efisien. Pengaturan flow SDM dimaksudkan untuk menentukan persyaratan tertentu pada SDM baru yang akan menggantikan SDM yang keluar dengan sumber daya yang bekerja secara efektif efisien.

Dalam prosesnya, perencanaan pengembangan SDM dilakukan melalui beberapa tahapan yaitu tahap analisis kebutuhan pengembangan, penentuan tujuan pengembangan serta perumusan strategi pengembangan. Untuk lebih jelasnya akan dipaparkan masing-masing tahapan sebagai berikut.

1) Analisis Kebutuhan Pengembangan SDM, Sebagai lembaga pendidikan Islam, pondok pesantren yang sejak keberadaannya hingga saat ini tetap eksis dalam memajukan pendidikan di Indonesia. Hal ini terlihat dari besarnya jumlah pondok pesantren yang ada di seluruh nusantara. Disadari atau tidak, keberadaan pondok pesantren telah memberikan kontribusi yang cukup besar bagi pembangunan masyarakat Indonesia khususnya yang ada di pedesaan (Qomar, 2007). Namun kenyataannya, tingginya jumlah pondok pesantren yang ada tidak diimbangi dengan peningkatan kualitas maupun kuantitas SDM yang dimilikinya. Kenyataan membuktikan bahwa tidak sedikit pondok pesantren yang ada bukannya menjadi semakin maju dan berkembang, malah sebaliknya stagnan atau bahkan mengalami kemunduran. Mereka tidak dapat menunjukkan lagi eksistensinya di tengah-tengah masyarakat. Hal ini salah satunya dipengaruhi minimnya atau bahkan tidak adanya inovasi yang dilakukan oleh pengurus pondok pesantren untuk mengembangkan kualitas atau kuantitas SDMnya. Pengembangan SDM bermanfaat untuk 1) Peningkatan produktifitas kerja. 2) Terwujudnya hubungan yang serasi antara atasan dan bawahan. 3) Tersedianya proses pengambilan keputusan yang cepat dan tepat. 4) Meningkatnya semangat kerja seluruh anggota dalam organisasi 5) Mendorong sikap keterbukaan manajemen. 6) Memperlancar jalannya komunikasi yang efektif. 7) Penyelesaian konflik secara fungsional (Siagian, 2003). Mengingat pentingnya pengembangan SDM sebagai salah satu cara untuk tetap mempertahankan eksistensi pondok pesantren di tengah-tengah masyarakat, maka pengurus pondok pesantren perlu melakukan analisis terhadap kebutuhan-kebutuhan pengembangan pondok pesantrennya. Analisis kebutuhan pengembangan dilakukan setidaknya untuk mengetahui seberapa besar kebutuhan pesantren akan SDMnya baik dilihat dari aspek kualitas maupun kuantitasnya. Secara umum SDM yang dimiliki oleh pesantren dapat dikelompokkan menjadi 2 (dua) yaitu sumber daya tenaga pengajar (ustadz) serta sumber daya pengurus santri (mudabbir).Kedua sumber daya ini memiliki peran dan tanggung jawab yang berbeda. Analisis terhadap kebutuhan-kebutuhan pengembangan ini dipergunakan un- 


\section{Manajemen Pengembangan SDM Di Pondok Pesantren As-Syafaah}

tuk mengukur sejauh mana pentingnya suatu program bagi peningkatan kualitas dan kuantitas SDM di pondok pesantren. Maka sebagai langkah awal bagi terpenuhinya jumlah SDM baik tenaga pengajar maupun mudabbir analisis rasio antara jumlah santri dengan tenaga pengajar dan mudabbir haruslah seimbang. Dalam hal ini untuk mencapai keefektifan dalam proses pembelajaran maupun pengurusan santri harus didukung oleh jumlah tenaga pengajar atau mudabbir yang cukup, maka program rekrutmen SDM perlu untuk dilakukan untuk menyeimbangkannya. Selain analisis terhadap kebutuhan jumlah tenaga pengajar atau mudabbir yang harus seimbang, Kualifikasi akademik menjadi salah satu persyaratan yang harus dipenuhi oleh tenaga pengajar pada sebuah lembaga pendidikan. Hal ini sebagaimana diatur dalam Undang-undang Guru dan Dosen No. 14 Tahun 2005 yang pada pasal 8 menyebutkan bahwa "Guru wajib memiliki kualifikasi akademik, kompetensi, sertifikat pendidik, sehat jasmani dan rohani, serta memiliki kemampuan untuk mewujudkan tujuan pendidikan nasional". Pernyataan dalam undangundang ini sekaligus menjadi salah satu dasar bagi pondok pesantren dalam menyusun program pengembangan yang akan dilaksanakannya.

2) Program Pendidikan dan Pelatihan menyatakan bahwa pengembangan SDM mencakup baik pendidikan yang meningkatkan pengetahuan umum dan pemahaman lingkungan maupun pelatihan yang menambah keterampilan dalam melaksanakan tugas yang spesifik. Pendidikan sebagai proses jangka panjang yang mencakup pengajaran dan praktek sistematik yang menekankan pada konsep-konsep teoritis dan abstrak. Sedangkan pelatihan sebagai salah satu proses belajar untuk memperoleh dan meningkatkan keterampilan di luar sistem pendidikan yang berlaku dalam waktu relatif singkat dan menggunakan metode yang lebih mengutamakan praktek daripada teori. Sementara Hasibuan, pendidikan dan pelatihan yaitu proses peningkatan keterampilan kerja baik teknis maupun manajerial. Pendidikan berorientasi pada teori, dilakukan dalam kelas, berlangsung lama. Sedangkan pelatihan berorientasi pada praktik, dilakukan dilapangan, berlangsung singkat. Dengan pendidikan dan pelatihan maka produktivitas kerja karyawan akan meningkat, kualitas dan kuantitas produksi semakin membaik. (Hasibuan, 2001). Pendidikan dan pelatihan ini dilakukan untuk memberikan pengalaman kepada tenaga pengajar agar bisa bekerja secara trampil dan produktif untuk menunjang keberhasilan pondok pesantren mengembangankan pendidikannya.

3) Pembentukan Budaya Pesantren Budaya Secara etimologis, menurut Koentjaraningrat menyatakan bahwa kata budaya berasal dari kata budhayah, bahasa Sanskerta, yang merupakan bentuk jamak dari kata buddhi yang berarti budi atau akal. Dengan demikian, 
kebudayaan dapat dikatakan "hal-hal yang berkaitan dengan budi dan akal (Koentjaraningrat, 1976). Pesantren dianggap sebagai sub-kultur (Wahid, 1984). Sebuah komunitas sosial yang memiliki budaya yang khas. Pesantren merupakan suatu komunitas tersendiri, dimana kiai, ustadz, santri dan pengurus santri hidup bersama dalam satu kampus berdasarkan nilai-nilai agama Islam, lengkap dengan norma-norma dan kebiasaan sendiri, yang secara eksklusif berbeda dengan masyarakat umum ia merupakan suatu keluarga besar di bawah pimpinan kiai atau ulama dengan dibantu ustadz (Mastuhu, 1994). Budaya pesantren merupakan budaya yang digali, dikembangkan dan disempurnakan oleh pendirinya untuk kemudian diwariskan kepada generasi-generasi sesudahnya. Dalam budaya pesantren ini, filsafat hidup pendirinya menjadi dasar yang kuat bagi penanaman nilai-nilai budaya tersebut kepada warga pesantren. Budaya pesantren ini menjadi ciri khas yang membedakan antara pesantren yang satu dengan pesantren lainnya sebagaimana diungkapkan bahwa budaya organisasi merujuk pada sistem pengertian bersama yang dipegang oleh anggota-anggota suatu organisasi yang membedakan organisasi tersebut dengan organisasi lainnya (Robbins \& Judge, 2008). Budaya pesantren yang dibentuk oleh pengasuh pondok pesantren merupakan cerminan dari visi dan misi pondok pesantren. Secara umum budaya-budaya yang dibentuk di pondok pesantren menekankan pada aspek pendalaman nilai-nilai keikhlasan, persaudaraan, tolong menolong serta kebebasan, nilai-nilai tersebut mutlak harus dimiliki oleh semua warga pesantren.

4) Evaluasi Pengembangan SDM pada Pondok Pesantren, Evaluasi adalah mengindentifikasi keberhasilan dan atau kegagalan suatu rencana kegiatan atau program (Suharto, 2006), rencana pengembangan SDM pesantren harus di evaluasi agar bisa di lihat tingkat keberhasilannya ataupun kekurangannya, karena pengembangan SDM pada pondok pesantren menekankan pada perubahan sikap dan perilaku tenaga pengajar ataupun mudabbir dalam menjalankan peran dan tanggungjawabnya, maka evaluasi terhadap prilaku sebagai hasil dari program pengembangan yang dilaksanakan menjadi faktor utama penilaian keberhasilan program yang dijalankan. Pemanfaatan momen-momen pertemuan rutin menjadi salah satu wadah untuk mengevaluasi setiap program yang sudah dan sedang dilaksanakan.dalam hal ini keterlibatan seluruh komponen yang ada di pondok pesantren untuk melakukan evaluasi sebagai bentuk kepedulian terhadap kondisi yang terjadi di pondok pesantren. Walau bagaimanapun juga keberadaan Kyai sebagai pengasuh pondok pesantren menjadi puncak dari setiap hirarki keputusan yang diambil di pondok pesantren. 


\section{Manajemen Pengembangan SDM Di Pondok Pesantren As-Syafaah}

Perencanaan Pengembangan SDM Terdapat beberapa tahapan yang ditempuh pesantren dalam melakukan perencanaan pengembangan SDMnya yaitu analisis kebutuhan pengembangan, tujuan pengembangan serta strategi pengembangan. Maka dalam konteks ini akan dijabarkan tentang temuan penelitian dari masing-masing tahapan fokus mulai dari perencanaan pengembangan SDM, Implementasi pengembangan SDM dan evaluasi pengembangan SDM. Pada fokus perencanaan pengembangan kurikulum, peneliti merincinya menjadi 1) Analisa Kebutuhan Pengembangan SDM, dalam kontek ini peneliti menemukan (a) perumusan perencanaan pengembangan SDMnya, Kyai sebagai pengasuh pesantren membentuk tim yang secara khusus menganalisis kebutuhan pengembangan SDM, (b) SDM dikelompokkan menjadi dua yaitu SDM tenaga pengajar (ustadz) dan SDM pengurus santri (mudabbir), (c) analisis kebutuhan pengembangan dilakukan untuk mengetahui kebutuhan SDM pada aspek kualitas dan kuantitas, (d) analisis rasio antara jumlah tenaga pengajar dengan jumlah santri dilakukan untuk merumuskan strategi pengembangan melalui program rekrutmen tenaga pengajar, (e) analisis rasio antara jumlah mudabbir dengan jumlah santri dilakukan untuk merumuskan strategi pengembangan melalui rekrutmen mudabbir, $(\mathfrak{f})$ analisis terhadap kebutuhan tenaga pengajar yang sesuai dengan spesifikasi tugasnya dilakukan untuk rekrutmen tenaga pengajar yang memiliki kualifikasi akademik sesuai kebutuhan pesantren, dan $(\mathrm{g})$ masih ditemukan adanya tenaga pengajar yang mengajar tidak sesuai dengan kualifikasi akademiknya bahkan belum selesai menempuh jenjang S1. 2) Penentuan Tujuan Pengembangan SDM. Dalam kontek ini peneliti menemukan tujuan pengembangan SDM terdiri atas: (a) pengembangan SDM dilakukan untuk memberikan pengetahuan serta wawasan kepada ustadz dan mudabbir sehingga mampu bekerja secara profesional, (b) perencanaan pengembangan SDM bertujuan untuk mengantisipasi dan merekam setiap perubahan yang terjadi, (c) pengembangan bertujuan untuk memastikan bahwa pesantren memiliki SDM yang berkualitas, (d) pengembangan dilakukan untuk menjawab tuntutan Undang undang Guru dan Dosen Nomor 14 Tahun 2005 yang mempersyaratkan tenaga pendidik harus memiliki kualifikasi akademik, kompetensi serta sertifikat pendidik, dan (e) pengembangan dilakukan dengan tujuan untuk mempertahankan eksistensi pesantren di tengah-tengah masyarakat. 3) Strategi Pengembangan, dalam kontek ini peneliti menemukan bahwa strategi pengembangan terdiri atas: (a) strategi pengembangan yang disusun mengacu pada hasil analisis kebutuhan pengembangan dipesantren yaitu terpenuhinya kuantitas dan kualitas SDM, (b) strategi pengembangan berkaitan dengan rekrutmen SDM, pendidikan dan pelatihan serta pembentukan budaya pesantren, (c) strategi pengembangan melalui program rekrutmen SDM dilakukan dengan tujuan untuk memenuhi standar kebutuhan jumlah tenaga 
pengajar dan mudabbir di pesantren, (d) strategi pengembangan melalui program pendidikan dan pelatihan dilakukan untuk meningkatkan kemampuan sumber SDM dalam menjalankan tugasnya secara profesional, dan (e) strategi pengembangan melului program pembentukan budaya pesantren dilakukan untuk merubah sikap dan perilaku SDM dalam menjalankan aktifitas.

b. Pada fokus Implementasi Pengembangan SDM, peneliti membaginya pada 1) Rekrutmen SDM, dalam kontek ini peneliti menemukan : (a) rekrutmen SDM dilakukan atas dasar kebutuhan SDM yang berkualitas, (b) melalui proses analisis kebutuhan pengembangan SDM, (c) umumnya dilakukan melalui penunjukan langsung oleh Kyai atas rekomendasi dari pembantu-pembantunya, 2) Program Pendidikan dan Pelatihan, Program ini terdiri atas: (a) pengembangan SDM dilakukan melalui pembagian tugas dan tanggung jawab kepada masing-masing lembaga yang bernaung dibawah pesantren untuk menyiapkan program-program pengembangan yang dianggap tepat, (b) Pengembangan SDM secara formal dapat berupa pengiriman alumni berprestasi untuk melanjutkan studinya ke perguruan tinggi (c) pengembangan SDM difokuskan pada peningkatan kualitas yang berkaitan dengan kemampuan bidang bahasa, kemampuan dalam bidang pembelajaran serta kemampuan dalam bidang dakwah, (c) pengembangan kemampuan tenaga pengajar dalam bidang pendidikan dapat dilakukan melalui kerjasama antara pesantren dengan lembaga-lembaga diluar pesantren seperti perguruan tinggi, (d) optimalisasi peran alumni yang telah lebih dahulu menyelesaikan pendidikannya pada jenjang yang lebih tinggi di luar pesantren dapat menjadi nilai tambah bagi peningkatan kemampuan SDM pesantren, dan (h) kegiatan pengajian yang rutin dilakukan oleh pesantren sekaligus juga sebagai bentuk eksistensinya ditengah tengah masyarakat. 3) Pembentukan Budaya Pesantren Temuan penelitian terdiri atas: (a) budaya pesantren merupakan salah satu ciri khas yang membedakan antara satu pesantren dengan pesantren lainnya, (b) budaya pesantren merupakan cerminan dari makna bersama, nilai, asumsi serta keyakinan yang dimiliki oleh komponen-komponen SDM dalam menjalankan aktivitasnya, (c) budaya pesantren dibentuk untuk tetap menjaga eksistensi pesantren ditengah-tengah masyarakat, (d) budaya pesantren yang dibentuk merupakan perwujudan dari visi dan misi pesantren, (e) budaya pesantren dibentuk untuk membiasakan warga pesantren melakukan hal-hal yang bersifat positif, (f) nilai-nilai keikhlasan, persaudaraan, kesederhanaan, tolong menolong serta kebebasan merupakan nilai-nilai dasar yang wajib dimiliki oleh warga pesantren.

c. Evaluasi Pengembangan SDM Pondok Pesantren meliputi: (a) pondok pesantren memanfaatkan momen pertemuan rutin yang dilaksanakan setiap minggu atau bulannya untuk mengevaluasi setiap program pengembangan yang telah dilaksanakan, (b) kegiatan evaluasi 


\section{Manajemen Pengembangan SDM Di Pondok Pesantren As-Syafaah}

melibatkan seluruh komponen yang ada dipesantren, (c) hirarki keputusan pada struktur birokrasi menjadikan Kyai sebagai puncak pengambilan keputusan, (d) kharisma Kyai menjadi legalitas bagi setiap aturan-aturan yang harus dipatuhi oleh warga pesantren, (e) buku poin sebagai salah satu alat kontrol bagi setiap aktivitas yang dilakukan oleh santri maupun ustadz, (f) faktor kedisiplinan menjadi permasalahan yang paling sering muncul dalam setiap proses pengembangan yang dilaksanakan, (g) optimalisasi peran dan tanggung jawab masingmasing kepala lembaga untuk mengontrol setiap proses yang berlangsung di pesantren, (h) perubahan sikap dan perilaku SDM dalam melaksanakan peran dan tanggung jawabnya di pesantren menjadi aspek evaluasi hasil pengembangan, (i) meningkatnya motivasi SDM untuk terus meningkatkan kemampuannya dalam proses pembelajaran menjadi salah satu ukuran keberhasilan pencapaian tujuan pengembangan, dan (j) jumlah santri terus meningkat setiap tahunnya membuktikan eksistensi pesantren sebagai dampak program pengembangan yang telah dilaksanakan.

\section{SIMPULAN}

Berdasarkan pembahasan sebelumnya tentang perencanaan pengembangan SDM pada pondok pesantren, dapat ditarik beberapa simpulan tentang tahapan perencanaan yaitu: (a) analisis kebutuhan pengembangan SDM, penentuan tujuan pengembangan, dan perumusan strategi pengembangan. Implementasi Pengembangan SDM pada Pondok Pesantren dilakukan melalui program-program berikut: (a) rekrutmen SDM, (b) program pendidikan dan pelatihan, dan (c) pembentukan budaya pesantren. Evaluasi pengembangan SDM pada pondok pesantren ditekankan pada perubahan sikap dan perilaku SDM dalam menjalankan peran dan tanggung jawabnya. Pemanfaatan momen-momen pertemuan rutin serta penggunaan alat evaluasi berupa buku poin menjadi salah satu upaya yang dilakukan pondok pesantren untuk dapat mengontrol setiap proses yang dilakukan dalam mengembangkan SDM.

Beberapa saran ditujukan untuk: (a) bagi penyelenggara pendidikan keagamaan khususnya pondok pesantren agar menjadikan hasil penelitian ini sebagai bahan kajian yang dapat membantu proses berfikir inovatif dalam mengembangkan SDM dapat menjadi dasar bagi pengaplikasian fungsi spiritual yang terkait dengan aqidah, syari'ah dan akhlak, (b) Kementerian Agama Cq. Direktorat Pendidikan Diniyah dan Pondok Pesantren agar dapat membuat kebijakan, keputusan dan semacamnya yang berkaitan dengan upaya-upaya pengembangan SDM pada pondok pesantren, baik berupa sarana prasarana, dana dan teknologi tepat guna agar program yang sudah, sedang dan akan dilaksanakan dapat memacu perubahan percepatan yang positif, (c) peneliti lain, hasil penelitian ini akan memberikan khazanah pengetahuan yang diharapkan dapat dikem- 
bangkan penelitian berikutnya berbasis pengembangan SDM dengan latar berbeda dan pendekatan penelitian yang lain, dan (d) pengembangan ilmu manajemen pendidikan dan sosial kemasyarakatan dan keagamaan agar menjadikan hasil penelitian ini sebagai referensi pemikiran serta pijakan bagi pengembangan ilmu manajemen pendidikan khususnya yang berkaitan dengan manajemen SDM.

\section{DAFTAR PUSTAKA /BIBLIOGRAPHY}

Bull, R. A. L. (1977). A Peaceful Juhad: Javanes education dan religion identity construction. Michigan: Arizona State University.

Dhofier, Z. (1982). Tradisi Pesantren: Studi tentang pandangan hidup Kyai. Jakarta: LP3ES.

Fatoni, S. (2006). Peradaban Islam; Desain awal peradaban, konsolidasi teologi, konstruk pemikiran dan pencarian madrasah. Jakarta: eLSAS.

Hasibuan, M. S. P. (2001). Manajemen Sumber Daya Manusia. Jakarta: Bumi Aksara.

Indonesia, P. R. (2003). Undang-Undang Nomor 20 Tahun 2003 Tentang Sisdiknas. Retrieved January 16, 2020, from https://kelembagaan.ristekdikti.go.id/wpcontent/uploads/2016/08/UU_no_20_th_2003.pdf

Koentjaraningrat. (1976). Kebudayaan, Mentalitet dan Pembangunan. Jakarta: Gramedia Pustaka Utama.

Mastuhu. (1994). Dinamika Sistem Pendidikan Pesantren. Jakarta: INIS.

Mondy, R. W. (2008). Human Resource Management. New Jersey: Pearson Education.

Nurdin, D. (2007). Manajemen Pendidikan dalam Ilmu dan Aplikasi Pendidikan bagian II : Ilmu pendidikan praktis. Bandung: IMTIMA.

Presiden Republik Indonesia. (2007). Peraturan Pemerintah Republik Indonesia Nomor 55 Tahun 2007. Retrieved January 16, 2020, from https://kelembagaan.ristekdikti.go.id/wpcontent/uploads/2016/08/PP_55_2007-Pendidikan-Agama-Keagamaan.pdf

Presiden Republik Indonesia. (2019). Undang-undang No. 18 Tahun 2019 Tentang Pesantren. Retrieved January 16, 2020, from https://m.hukumonline.com/pusatdata/detail/lt5dae6ed07247f/node/lt5c5c06acb22b1/u u-no-18-tahun-2019-pesantren\#

Qomar, M. (2007). Pesantren dari Transformasi Metodologi Menuju Demokratisasi Institusi. Jakarta: Erlangga.

Raharjo, D. (1995). Pesantren dan Pembaharuan. Jakarta: LP3ES.

Robbins, S. P., \& Judge, T. A. (2008). Perilaku Organisasi Buku 2. Jakarta: Salemba Empat. 
Siagian, S. P. (2003). Filsafat Administrasi. Jakarta: Bumi Aksara.

Steenbrink, K. A. (1994). Pesantren Madrasah Sekolah, Pendidikan Islam dalam Kurun Modern. Jakarta: LP3ES.

Suharto, E. (2006). Membangun Masyarakat Memperdayakan Rakyat. Bandung: Rafika Media.

Terry, G. R. (1992). Dasar-dasar Manajemen. Jakarta: Bumi Aksara.

Tunggal, A. W. (2002). Manajemen: Suatu pengantar. Jakarta: Rineka Cipta.

Wahid, A. (1984). Bunga Rampai Pesantren: Kumpulan karya tulis. Jakarta: Dharma Bhakti.

Zarkasyi, A. F. (1998). Pondok Pesantren Sebagai Lembaga Pendidikan dan Dakwah. In Solusi Islam atas Problematika Umat. Jakarta: Gema Insani Press.

Ziemek, M. (n.d.). Pesantren dan Perubahan Sosial. Jakarta: P3M. 